\title{
TATA PENGELOLAAN ALOKASI DANA DESA (ADD) DI DESA MERERAI DUA
}

\author{
Darmawan, Petrus Atong, Imam Asrori \\ Fakultas Ilmu Sosial dan Ilmu Politik Universitas Kapuas Sintang \\ Jln. Oevang Oeray Nomor: 92 Baning Kota Sintang. \\ Email:atong-petrus@gmail.com
}

\begin{abstract}
Abstrack: Penelitian melakukan kajian tentang aspek Peran Kepala Desa, dan Pengelolaan Anggaran yaitu terhadap Anggaran Dana Desa (ADD) yang diterima oleh Desa Merarai Dua setiap tahunnya, terutama Peran Kepala Desa dalam bagaimana melakukan pengelolaan terhadap Anggaran Dana Desa (ADD) untuk Tahun 2019-2020. Dalam tata pengelolaan Anggaran Dana Desa sangatlah signifkan dan penting. Kepala Desa bersama dengan perangkatnya adalah personil yang langsung bersentuhan dengan perencanaan, penggunaan sekaligus sebagai evaluator melekat dalam implementasi penggunaan anggaran dana desa. Bersama dengan Ketua dan perangkat Badan Permusyawaratan Desa (BPD), Tokoh Adat, Tokoh Agama, Tokoh Masyarakat dan semua keterwakilan masyarakat desa, Alokasi Dana Desa yang dikucurkan oleh pemerintah pusat tersebut dirancangkan bersama penggunaannya serta diputuskan bersama dalam rapat atau musyawarah desa yang dilakukan atau diselenggarakan oleh pihak eksekutif (pemerintahan desa).Sementara tujuh puluh persen dari total anggaran atau Alokasi Dana Desa yang diterima setiap tahun oleh desa dari pemerintah pusat, dialokasikan untuk pembangunan yang disesuaikan dengan kebutuhan Desa Merarai Dua. Hal apa yang penting dalam pembangunan di Desa Merarai Dua, ditentukan bersama dalam rapat permusyawaratan desa yang diselenggarakan oleh pihak eksekutif yang diikuti oleh keterwakilan seluruh masyarakat Desa Merarai Dua.
\end{abstract}

\section{Kata Kunci: Tata, Pengelolaan, Anggaran, Dana, Desa}

Undang-Undang Nomor 6 tahun 2014 tentang desa dan Peraturan Perintah No. 43 tahun 2014 tentang petunjuk teknis Undang-Undang nomor 6 tahun 2014 mengamanatkan penggunaan ADD perlu Rencana Alokasi Pendapatan dan Belanja Desa (RAPBD Desa) di Desa Merarai DuaTahun 2019 yang telah dibuat oleh Kepala Desa Merarai Dua beserta BPD Merarai Dua untuk mendapatkan persetujuan. Persetujuan tersebut dihadiri oleh Kepala Desa, Ketua Badan Permusyawaratan Desa (BPD) Sekretaris Desa, Kaur Desa, Tokoh Agama, Tokoh Adat, dan Tokoh Masyarakat lainnya. Musyawarah ini bertujuan agar perencanaan sesuai dengan skala prioritas, serta penggunaan Alokasi Dana Desa di Desa Merarai Dua dilakukan dengan transparan dan bisa dipertanggungjawabkan. Alokasi Dana Desa yang telah diterima oleh Desa Merarai DuaTahun 2019.Adapun yang menjadi tujuan dari penelitian ini adalah untuk mengetahui 1.Peran Kepala Desa dalam Penggunaan Alokasi Dana Desa Tahun 2019Di Desa Merarai DuaKabupaten Sintang. Diharapkan melalui penelitian ini dapat memberikan sumbangan pemikiran bagi Pemerintah Desa Merarai Dua Kabupaten Sintang dalam Penggunaan Alokasi Dana Desa di masa yang akan datang.

\section{METODE PENELITIAN}

Tujuan penelitian deskriptif adalah untuk membuat deskripsi, gambaran atau lukisan secara sistematis, faktual dan akurat mengenai fakta-fakta, sifat-sifat serta hubungan antar fenomena yang diselidiki". Dalam penelitian deskriptif ini, penulis ingin mendeskripsikan tentang proses pelaksanaan penggunaan Alokasi Dana Desa di Desa Merarai Dua serta melihat faktor-faktor yang mempengaruhi proses Pelaksanaan Penggunaan Alokasi Dana Desa di Desa Merarai Dua tersebut.Subjek dalam penelitian ini berjumlah tiga orang, yang terdiri dari: Kepala Desa Merarai Dua, dipilih karena yang bersangkutan menguasai informasi dan persoalan yang sedang diteliti dan Ketua Badan Permusyawaratan Desa (BPD). Pengumpulan data pada penelitian kualitatif membutuhkan teknik-teknik kualitatif pula. Pada umumnya dalam penelitian kualitatif, dapat memilih beberapa teknik pengumpulan data antara lain: (1). Oservasi partisipasi atau nonpartisipan; (2). Wawancara; (3). Analisis dokumen. (4). Catatan harian peneliti (rekaman pengalaman dan kesan penliti pada saat pengumpulan data." Analisis data merupakan kegiatan setelah data dari seluruh responden atau sumber data terkumpul.

\section{TINJAUAN PUSTAKA}

Dalam Peraturan Menteri Dalam Negeri Nomor: 37 Tahun 2007 tentang pedoman Pengelolaan Alokasi Dana Desa, mekanisme penyaluran dana Alokasi Dana Desa adalah sebagai berikut : 1) Pencairan Alokasi Alokasi Dana Desa dapat dilakukan apabila sudah dialokasikan dalam 
150. Fokus, Volume 18, Nomor 2, September 2020, hlm. 149 - 155

Alokasi Pendapatan dan Belanja desa yang ditetapkan dengan peraturan Desa. 2) Mekanisme penyaluran dana yaitu a) Kepala Desa membuka rekening atas nama Pemerintah Desa kepada Bank pembangunan Daerah Kalimantan Barat Cabang Sintang, b) Setiap penarikan dana Alokasi Dana Desa harus dilakukan oleh 2 (dua) Pejabat Desa yaitu Kepala Desa dan Bendahara Desa, c) Penyaluran Dana Alokasi Dana Desa dilakukan secara bertahap dan di transfer ke rekening masing-masing pemerintah Desa dan d) Penyaluran Alokasi Dana Desa tahap berikutnya dapat dilaksanakan setelah dana Alokasi Dana Desa tahap sebelumnya dipertanggungjawabkan. 3) Tahap Penyaluran ADD dilakukan dalam 4 (empat) tahap. Tahapan tersebut terdiri dari Tahap I sebesar 25 persen dalam bulan Februari sedang tahap II, III dan IV akan di salurkan setiap triwulan.

Oleh Undang-Undang terutama UndangUndang Nomor: 7 tahun 2007, penggunaan Alokasi Dana Desa sudah diatur atau ditetapkan sedemikian rupa. Selain pengaturan penggunaan dananya sudah ditetapkan, juga sistem pengawasan dan pelaporannya melekat bersama. Proses pencairan ADD adalah sebagai berikut; dari pemerintah Pusat, Pemerintah Propinsi, Pemerintah Kabupaten, baru kePemerintah Desa. Menurut Terry (dalam Syafiie, 2011:101) Penggunaan adalah sebagai berikut: " ...is setting all members of the group to want to achieve and to strike to achieve the objective willingly and keeping with the managerial planning and organizing efforrts." Maksudnya dapat diartikan sebagai berikut, ...adalah suatu tindakkan untuk mengusahakan agar seluruh anggota kelompok berkenan berusaha mencapai sasaran-sasaran yang telah ditentukan agar sesuai dengan perencanaan managerial dan usaha-usaha yang dilakukan oleh organisasi.

Adapun aturan atau ketetapan penggunaan Alokasi Dana Desa adalah sebagai berikut menurut Undang-Undang Nomor: 7 Tahun 2007: 1) Penggunaan Anggaran Dana Alokasi Desa adalah sebesar 30\% untuk belanja operasional pemerintah Desa $70 \%$ untuk biaya pemberdayaan masyarakat. 2) Bagi belanja pemberdayaan masyarakat digunakan untuk: (a) biaya dalam perbaikan sarana publik dalam skala kecil, (b) penyertaan modal usaha masyarakat melalui BUMDesa, (c) biaya untuk ketahanan pangan, (d) perbaikan pemukiman dan lingkungan, (e) teknologi tepat guna, (f) perbaikan kesehatan dan pendidikan, (g) pembangunan sosial, (h) dan sebagainya yang dianggap penting.

Menurut Peraturan Bupati Sintang Nomor: 14 tahun 2009 tentang Pedoman Pengelolaan Keuangan Desa di Wilayah Kabupaten Sintang tahapan Pelaksanaan Alokasi di Desa Merarai Dua sebgai berikut : 1) Pelaksanaan kegiatan-kegiatan dan pelaksanaanya bersumber dari ADD dalam APBDesa sepenuhnya dilaksanakan oleh Tim Pelaksana Desa ,2) Penggunaan Anggaran Dana Alokasi Desa adalah sebesar 30\% untuk belanja operasional pemerintah Desa 70\% untuk biaya pemberdayaan masyarakat. 3) Bagi belanja pemberdayaan masyarakat digunakan untuk: a) biaya dalam perbaikan sarana publik dalam skala kecil. b) Penyertaan modal usaha masyarakat melalui BUMDesa. c) Biaya untuk ketahanan pangan. d). Perbaikan pemukiman dan lingkungan. e). Teknologi tepat guna. f). Perbaikan kesehatan dan pendidikan.g). Pembangunan sosial. h). Dan sebagainya yang dianggap penting

Perangkat Desa Desa merupakan modal utama di dalam penyelenggaraan Pemerintah Desa, karena merupakan daya manusia yang merupakan sumber daya utama yang menentukan keberhasilan penyelenggaraan Pemerintahan Desa. Seiring dengan berlakunya Undang-undag Nomor 32 tentang Pemerintahan Daerah dan telah diterbitkan pula Peraturan Pemerintah Nomor 72 tahun 2005 tentang Desa, dimana memuat akan kewenangan Desa yang sangat besar dan berhak mengatur urusan rumah tangganya sendiri sesuai prinsip demokratis.Masalah keterbatasan sumber daya aparatur Desa baik dari segi kualitas maupun kuantitas dari Kepala Desa, Sekretaris Desa, Kepala Urusan hingga sampai kepala Dusun. Diharapkan seluruh aparatur pemerintah Desa yang ada dapat meningkatkan kemampuan dan keahliannya sehingga dapat menjalankan tugas dan fungsinya sesuai dengan pembagian pekerjaan yang telah ditetapkan.

\section{HASIL DAN PEMBAHASAN PENELITIAN Pelaksanaan Kebijakan}

Pelaksanaan Kebijakan Alokasi Dana Desa (ADD) memerlukan melalui beberapa tahap yang seharusnya dirancang dan dilakukan secara tepat dan efisien. Karena pelaksanaan kebijakan ini melibatkan beberapa pihak yakni Perangkat Desa, BPD, dan Masyarakat maka sangat diperlukan perencanaan, penggunaan dan pengawasan, maka sangat diperlukan suatu manajemen yang baik dan tepat. Tahap penetapan rencana adalah tahap dalam menetapkan landasan hukum bagi rencana pembangunan yang telah dihasilkan menjadi sebuah produk hukum sehingga mengikat semua pihak untuk melaksanakannya.Pelaksanaan rancangan anggaran tersebut berjalan tidak seperti yang diharapkan. Kurangnya pengawasan dari Badan Permusyawaratan Desa menyebabkan Kepala Desa dan aparaturnya menggunkan alokasi dana desa tersebut secara tidak terarah. Lemahnya 
pengawsan dari BPD bukan saja berpengaruh pada pembangunan yang harus di tangani tetapi juga pada pelaporan keuangan yang tidak di lakukan dalam bentuk Laporan Pertanggungjawaban kepada masyarakat.

Sehubungan dengan penetapan rencana kegiatan dalam pemanfaatan ADDMerarai Dua, Kepala Desa mengatakan bahwa tahapan-tahapan dalam proses perencanaan, yaitu : 1) Sekretaris Desa dan perangkat desa lainnya dengan dibantu oleh Bendahara Desa menyusun rencana kegiatan dalam rangka penyusunan rencana APBDes DedaiTahun 2019.2) Rancangan APBDes Merarai DuaTahun 2019 selanjutnya diserahkan kepada Kepala Desa untuk mendapatkan persetujuannya. 3) Pada minggu kedua bulan Januari dilaksanakan kembali rapat antar Kepala Desa dengan BPD untuk mendapatkan persetujuan dari BPD terhadap rancangan APBDes Merarai DuaTahun 2019. 4) Rancangan APBDes Merarai Duayang telah disetujui BPD selanjutnya disampaikan ke kantor Kecamatan Sungai Tebelian untuk diasistensi. Asistensi di kecamatan kurang lebih 10 hari karena menunggu rancangan APBDes lainnya.5) Rancangan APBDes Merarai Duabersama-sama dengan rancangan APBDes lainnya kemudian disampaikan oleh pihak kecamatan kepada bagian Pemerintah Desa (Pemdes) Sekretariat Daerah Kabupaten Sintang. Di bagian Pemdes, APBDes, APBDes Merarai Duamenunggu terkumpulnya APB desa lainnya memakan waktu kurang lebih 20 hari untuk selanjutnya disampaikan kepada BPKKD.

Selanjutnya di BPKKD proses asistensi memakan waktu hampir satu bulan lamanya karena menunggu terkumpulnya rancangan APBDes dari semua desa se Kabupaten Sintang, baru disampaikan ke Bagian Hukum Setda Kabupaten Sintang untuk diteliti.Proses penelitian di bagian hukum kurang lebih 10 hari dan untuk mendapatakan pengesahan dari Sekdabaru diterima kembali oleh Desa Merarai Dua.Setelah melewati proses yang begitu panjang akhirnya rancangan APBDes Merarai Duaditetapkan oleh Kepala Desa Merarai Duadengan persetujuan BPD menjadi Peraturan Desa (Perdes) Merarai Duayaitu Perdes Nomor 4Tahun 2019 tentang APBDes Merarai DuaTahun 2019. Proses penyusunan rencana kegiatan dalam pemanfaatan ADD Desa Merarai Duatentunya melibatkan berbagai pihak. Adapun pihak-pihak yang berkepentingan dalam proses tersebut antara lain Kepala Desa beserta perangkat desanya, Ketua Badan Permusyawaratan Desa dan seluruh anggota BPD, Kepala Dusun dan Ketua RT di lingkungan Desa Merarai Duayang merupakan representasi atau perwakilan dari seluruh lapisan masyarakat Desa Merarai Dua. Selain itu, Kepala Desa Merarai Dualebih mengetahui data-data serta kondisi riil desanya, apa yang menjadi kebutuhan dan keperluan bagi kelangsungan pemerintahan desa maupun masyarakat desanya. Sehubungan dengan proses penyusunan rencana kegiatan dalam pemanfaatan ADD Desa Merarai DuaTahun 2019, maka peran Kepala Desa adalah sebagai berikut: 1). Memprakarsai, mengkoordinir, serta memimpin langsung rapat/musyawarah warga dalam menyusun rencana kegiatan dalam rangka pemanfaatan ADD tersebut.

Adapun kegiatan rapat dilaksanakan sebanyak tiga kali. 2).Memberikan pemaparan serta penjelasan mengenai besarnya ADD Tahun 2019 kepada forum rapat serta menyampaikan bersarnya persentase kegiatan untuk pemberdayaan dan operasional baik operasional Pemdes maupun BPD. 3).Menyampaikan usulan rencana kegiatan sesuai dengan program dan kegiatan yang merupakan prioritas dan sesuai dengan kebutuhan untuk dilaksanakan pada Tahun 2019 untuk selanjutnya dibahas di dalam forum rapat.4).Memberikan kesempatan kepada peserta rapat untuk menyampaikan usulan kegiatan dalam rangka pemanfaatan ADD tersebut.

Apabila terdapat sanggahan, protes, konflik maupun perbedaan pendapat pada saat rapat, maka Kepala Desa mengambil jalan tengah, memberikan masukan agar permasalahan dapat diselesaikan dengan sebaik-baiknya, memberikan pengertian kepada peserta rapat bahwa jumlah dana ADD sangat terbatas, serta rencana kegiatan dalam pemanfaatan ADD ini adalah merupakan prioritas dan kebutuhan yang sangat penting dalam menunjang kegiatan dalam memberikan pelayanan kepada masyarakat. 5).Setelah rencana kegiatan ditetapkanyang merupakan hasil kesepakatan bersama, maka Kepala Desa mengkoordinir penyusunan rencana kerja dan anggaran ADD yang merupakan rancangan peraturan desa mengenai APBDes Merarai DuaTahun 2010. 6).Menetapkan rancangan peraturan desa tersebut menjadi Peraturan Desa yang telah mendapat persetujuan bersama BPD.

Sedangkan peran Sekretaris Desa beserta perangkatnya dalam kaitannya dengan perencanaan pemanfaatan ADD Desa Merarai Duaadalah membantu Kepala Desa dalam hal penyiapan administrasi, persiapan penyelenggaraan rapat-rapat, penyusunan rencana kerja dan anggaran ADD, serta penyusunan Raperdes tentang APBDes Merarai DuaTahun 2019. Peran BPD dalam pemanfaatan ADD Desa Merarai DuaTahun 2019 antara lain adalah : 1).Menampung dan menyalurkan aspirasi masyarakat baik yang berasal dari anggota BPD, Kepala Dusun, Ketua RT maupun masyarakat untuk selanjutnya disampaikan kepada Kepala Desa dalam forum 
rapat penyusunan rencana kegiatan. 2).Memberikan masukan, saran dan pendapat serta sanggahan apabila rencana kegiatan yang disampaikan tidak sesuai kebutuhan dan melenceng dari ketentuan-ketentuan pengelolaan ADD.3).Memonitor penyelenggaraan rapat-rapat agar berjalan sebagaimana mestinya.4) Membahas usulan rencana kegiatan yang merupakan rancangan peraturan desa bersama dengan Kepala Desa. 4).Memberikan persetujuan dan menetapkan Peraturan Desa tentang APBDesMerarai DuaTahun 2019 bersama Kepala Desa.Lembaga Kemasyarakatan yang terlibat dalam hal ini adalah Kepala Dusun dan Ketua RT se Desa Merarai Duayang berperan dalam menampung dan menyalurkan aspirasi masyarakat dalam rangka pemanfaatan dana ADD. Aspirasi tersebut berupa usulan rencana kegiatan yang disampaikan kepada Kepala Desa dalam rangka pemanfaatan ADD Desa Merarai DuaTahun 2019.

Desa Merarai Duatelah mendapatkan bantuan dari pemerintah daerah dana pengembangan beberapa kali salah satunya adalah Alokasi Dana Desa(ADD. Berdasarkan hasil wawancara dengan Kepala Desa Merarai Duamengatakan bahwa "Desa Merarai Duatelah melakukan langkah-langkah persiapan dan pemanfaatan dan perencanaan kegiatan dari dana ADD dengan melaksanakan beberapa kali rapat yang melibatkan unsur dari pemerintah desa, BPD, serta dari lembaga kemasyarakatan". Adapun tujuan dari dilaksanakan rapat-rapat tersebut adalah untuk mendengar masukan dan usulan dari masyarakat melalui anggota BPD maupun dari Kepala Dusun dan Ketua RT se Desa Merarai Dua. Selain itu untuk menentukan kegiatan yang akan dilaksanakan pada Tahun 2019 dengan memperhatikan prioritas/kebutuhan dan kemampuan keuangan yang ada. Dengan dilaksanakan pertemuan atau rapat-rapat tersebut diharapkan pemanfaatan ADD menjadi lebih optimal dan rapat dipertanggungjawabkan secara bersama-sama oleh pihak-pihak yang terkait dan seluruh masyarakat Desa Merarai Dua bahkan secara formal oleh pemerintahan Desa.Perencanaan itu sangat menentukan dalam rangka pencapaian tujuan yang diinginkan. Karena sangat erat kaitannya dengan tujuan yang ingin dicapai, maka tahapan-tahapan dalam penyusunan rencana mempunyai arti yang sangat penting.

Adapun tahapan-tahapan tersebut adalah: 1).Menetapkan dan merumuskan tujuan atau permasalahan yang akan dipecahkan, 2).Menentukan pilihan (alternatif) kegiatan yang akan dilaksanakan. 3).Penetapan pilihan (alternatif) kegiatan yang akan dilaksanakan. 4).Menyusun kegiatan dan perhitungan biaya.Dapat dijelaskan bahwa ada tiga tahap yang dilaksanakan oleh Desa
Merarai Duasesuai dengan ketentuan teoritis, yaitu : 1). Menetapkan dan merumuskan tujuan atau permasalahan yang akan dipecahkan; 2). Menentukan pilihan/alternatif kegiatan yang akan dilaksanakan (Identifikasi berbagai alternatif); 3). Penetapan pilihan/alternatif kegiatan yang akan dilaksanakan (pemilihan alternatif terbaik). Sedangkan tahapan-tahapan yang tidak atau belum dilaksanakan, yaitu : 1). Mengumpulkan data dan memerlukan dugaan-dugaan atau ramalan-ramalan di masa yang akan datang; 2). Analisa data dan dugaan/ramalan; dan 3). Penilaian terhadap alternatif tersebut. Ketiga tahapan tersebut tidak dapat dilaksanakan disebabkan karena rencana kegiatan yang akan dilaksanakan merupakan kegiatan dalam skala kecil dengan jumlah dana yang juga terbatas, sehingga tidak diperlukan adanya dugaan-dugaan atau ramalan-ramalan serta analisis terhadap dugaan/ramalan tersebut. Demikian juga halnya dengan penilaian terhadap berbagai alternatif kegiatan yang akan direncanakan.

\section{Penggunaan Dana}

Rencana kegiatan yang telah ditetapkan oleh semua komponen yang terlibat dalam pemanfaatan ADD Desa Merarai Dua, secara keseluruhan telah sesuai dengan skala prioritas, tujuan dan sasaran yang ingin dicapai. Sebagai contoh, kegiatan pembangunan desa merupakan agenda pokok pemerintahan Desa Merarai DuaTahun 2019 walaupun memerlukan jumlah anggaran yang tidak sedikit. Demikian juga halnya dengan pembangunan jembatan Dusun I, II, dan IIIdalam rangka menunjang PAD Desa Merarai Dua, serta kegiatan lainnya merupakan kebutuhan yang urgen untuk dilaksanakan.Hal yang sama juga diungkapkan oleh Ketua BPD bahwa yang terlibat dalam penggunaan Alokasi Dana Desa adalah perangkat desa dan BPD tetapi yang lebih dominan adalah kepala desa. Pengambilan ADD melalui dua tahap, yakni tahap pertama $60 \%$ dan tahap kedua 40\%.APBDes yang telah disetujui oleh Sekda, dibadanhukumkan, kemudian dilaksanakan oleh desa.Penggunaan Anggaran Dana Desa ini diawasi oleh BPD.Hasil penelitian membuktikan bahwa penggunaandana mengacupada ketentuan APBDes, namun pelaksanaannya lebih dominan dilakukan oleh kepala desa, disesuaikan dengan perkembangan di lapangan. Pengawasan penggunaan ADD BPD memang dilakukan tetapi belum maksimal karena dalam penggunaan ADD masih ada yang alokasinya dipindahkan tetapi tanpa persetujuan BPD terlebih dahulu.

Pengawasan Dana dan Dukungan Sumber daya Pengawasan yang dilakukan oleh Badan Pengawasan Daerah yang sekarang berubah menjadi Inspektorat, Pemerintahan Desa 
bekerjasama dengan pemerintah Kecamatan dan Badan Permusyawaratan Desa, mencakup memeriksa dan meminta penjelasan penggunaan anggaran dana desa, mengawali penggunaan dana, serta meminta pertangungjawaban dalam bentuk laporan tertulis dari Kepala Desa dan semua pengurus desa. Dalam pemeriksaan juga di lakukan oleh pemeriksa untuk mengetahui dan menilai dengan cermat dan seksama kenyataan yang sebenarnya mengenai sasaran dan obyek yang diperiksa apakah sesuai dengan peraturan perundang-undangan yang berlaku atau rencana yang telah di tetapkan. Direktorat mempunyai tugas melakukan pembinaan dan pengawsan terhadap pelaksanaan kegiatan dengan melakukan pemeriksaan atas perencanaan, pelaksanaan dan laporan yang telah di buat secara tertulis.

Kepatuhan prosedur pengawasan juga belum dilaksankan sesuai dengan stándar yang ada, ini karena kurang proaktifnya anggota Badan Permusyawaratan Desa melaksanakan pengawasan. Berkaitan dengan prosedur pengawasan sesuai dengan Peraturan Pemerintah Nomor: 72 Tahun 2005 Tentang Desa menyatakan Badan Permusyawaratan Desa adalah lembaga yang merupakan perwujudan demokrasi dalam penyelengaraan dan pengawasan desa sebagai unsur penyelenggara pemerintah desa terdapat beberapa hal yang menjadi acuan bagi Badan Permusyawaratan Desa dalam melakukan pengawasan, termasuk berkaitan dengan prosedur yang harus di terapkan: 1).Menetapkan pengaturan kewenangan dan pengaturan, 2).Memberikan pedoman pelaksanaan tugas pembantuan, 3 ). Memberikan pedoman penyusunan peraturan desa dan peraturan Kepala Desa, 4).Memberikan pedoman teknis pelaksanaan dan pengembangan, 5).Melakukan pengkajian dan penelitian terhadap pelaksanaan, 6).Melakukan evaluasi dan pengawasan

Dalam rapat tersebut dihadiri oleh Kepala Desa beserta perangkat desa, seluruh anggota BPD, Kepala Dusun dan seluruh Ketua RT seDesa Merarai Dua. Dalam rapat tersebut, Kepala Desa dan dibantu oleh Bendahara Desa menjelaskan mengenai besarnya ADD yang diterima oleh Desa Merarai Duauntuk Tahun 2019. Selain itu juga dijelaskan ketentuan mengenai persentase pembagian ADD yaitu 30\% untuk operasional pemerintahan desa dan BPD, dan $70 \%$ untuk kegiatan publik dan pemberdayaan masyarakat.

Selanjutnya dari $30 \%$ dana ADD tersebut dibagi-bagi lagi menjadi $60 \%$ untuk belanja operasional pemerintah desa dan $40 \%$ untuk operasional BPD. Setelah diketahui pembagian persentase tersebut, maka Kepala Desa melimpahkan pengalokasian atau penggunaan dana kepada masing-masing pihak terkait, yaitu untuk kegiatan pemberdayaan dan operasional Pemdes disusun oleh Kepala Desa, Sekretaris Desa beserta perangkatnya, Bendahara Desa, Kepala Dusun, dan para Ketua RT. Sedangkan untuk operasional BPD disusun oleh ketua BPD dan anggota BPD. Pada sisi lain Menentukan pilihan kegiatan yang akan dilaksanakan disesuaikan dengankebutuhan dana yang ada. Rapat ini juga di hadiri oleh masingmasing unsur terkait yaitu dari pemerintah desa, BPD, Kepala Dusun, dan para ketua RT. Rapat ini juga bertujuan untuk mendengarkan sanggahan, saran dan masukan dari BPD, Kepala Dusun maupun Ketua RT mengenai rencana kegiatan ADD Tahun 2019 tersebut. Langkah selanjutnya adalah mengumpulkan/merekap semua usulan rencana kegiatan sebagaimana telah disebutkan di atas sebagai dasar dalam penyusunan rencana kegiatan dalam rangka pemanfaatan ADD dan penyusunan APBDesMerarai Dua. Adapun pihak yang melakukan rekapitulasi adalah Sekretaris Desa dibantu oleh Bendahara Desa. Kegiatan dan program yang terarah akan mempermudah Badan permusyawaratan Desa dalam melakukan langkahlangkah pengawasan secara bertahap dan berkesinambungan.

Proses penyampaian Raperdes APBDes Merarai Duakepada BPD untuk dibahas secara bersama-sama baru dilaksanakan pada minggu kedu bulan Januari 2019, padahal menurut ketentuanPeraturan Daerah Kabupaten Sintang Nomor 16 Tahun 2006Tentang Kedudukan Keuangan Desa adalah bahwa Rancangan Peraturan Desa disampaikaan paling lambat minggu pertama bulan November tahun sebelumnya.Waktu yang diperlukan untuk penetapan Raperdes menjadi APBDes Merarai Duamulai dari persetujuan BPD hingga selesainya proses asistensi memerlukan waktu yang cukup lama kurang lebih 2,5 bulan.Berkaitan dengan poin (1) dan (2) di atas menyebabkan keterlambatan dalam proses penetapan Peraturan Desa tentang APBDesMerarai Duayaitu pada tanggal 2 April 2019, padahal menurut Ketentuan Peraturan Daerah Kabupaten Sintang Nomor:16 Tahun 2006Tentang Kedudukan Keuangan Desa disebutkan bahwa Peraturan Desa tentang APBDes ditetapkan paling lambat 1 (satu) bulan setelah APBD Kabupaten ditetapkan pada tanggal 31 Desember 2011. Adanya keterlambatan dalam proses penetapan dapat dimaklumi karena dari awal sejak proses penyusunan rencana kegiatan dilaksanakan sudah mengalami keterlambatan. Bahkan jauh-jauh hari sebelumnya sosialisasi yang dilakukan oleh Bagian Pemdes Sekretariat Daerah Kabupaten Sintang juga terlambat. Selain itu, pengelolaan ADD ini merupakan pertama kali dilaksanakan oleh Pemerintah Kabupaten 
Sintangkhususnya Desa Merarai Duasehingga memerlukan waktu yang cukup untuk memahami pedoman serta ketentuan yang ada. Kondisi ini pada akhirnya mempengaruhi proses penetapan Raperdes APBDesMerarai DuaTahun 2019.

Setelah rencana kegiatan ditetapkan yang merupakan hasil kesepakatan bersama, maka Kepala Desa mengkoordinir penyusunan rencana kerja dan anggaran ADD yang merupakan rancangan peraturan desa mengenai APBDes Merarai DuaTahun 2019.Menetapkan rancangan peraturan desa tersebut menjadi Peraturan Desayang telah mendapat persetujuan bersama BPD. Berdasarkan hasil pengamatan, dapat dikatakan bahwa peran Kepala Desa Merarai Duasangat besar dan berpengaruh terhadap jalannya musyawarah. Hal ini dapat terlihat dari langkah-langkah yang dilakukan oleh Kepala Desa dalam memprakarsai, memimpin rapat, serta mengkoordinir penyusunan rencana kegiatan dalam rangka penyusunan Raperdes Merarai DuaTahun 2019.

Peran BPD dalam pemanfaatan ADD Desa Merarai DuaTahun 2019 antara lain adalah Menampung dan menyalurkan aspirasi masyarakat baik yang berasal dari anggota BPD, Kepala Dusun, Ketua RT maupun masyarakat untuk selanjutnya disampaikan kepada Kepala Desa dalam forum rapat penyusunan rencana kegiatan.Memberikan masukan, saran dan pendapat serta sanggahan apabila rencana kegiatan yang disampaikan tidak sesuai kebutuhan dan melenceng dari ketentuan-ketentuan pengelolaan ADD.Memonitor penyelenggaraan rapat-rapat agar berjalan sebagaimana mestinya.Membahas usulan rencana kegiatan yang merupakan rancangan peraturan desa bersama dengan Kepala Desa.Memberikan persetujuan dan menetapkan Peraturan Desa tentang APBDes Merarai DuaTahun 2019 bersama Kepala Desa.Lembaga Kemasyarakatan yang terlibat dalam hal ini adalah Kepala Dusun dan Ketua RT se Desa Merarai Duayang berperan dalam menampung dan menyalurkan aspirasi masyarakat dalam rangka pemanfaatan dana Alokasi Dana Desa. Aspirasi tersebut berupa usulan rencana kegiatan yang disampaikan kepada Kepala Desa dalam rangka pemanfaatan ADD Desa Merarai DuaTahun 2019. Badan Permusyawaratan Desa memiliki kewenangan mengawasi dan menilai melalui ruang evaluasi demi perbaikan kinerja aparatur desa.

Pada dasarnya telah ditemukan adanya kendala dianggap masih rendahnya kapasitas sumber daya manusia aparatur desa dalam proses penyusunan pemanfaatan ADD Desa Merarai DuaTahun 2019 karena semua pihak yang terlibat dalam proses penyusunan tersebut masih minim pemahaman penataan administrasi keuangan terutama dalam proses penyusunan kegiatan dan penyusunan dokumen laporan pertanggungjawaban. Keterbatasan pengetahuan tentang administrasi sangat mempengaruhi kualitas kerjaperangkatdesa. Walaupun kenyataannya di dalam rapat penyusunan kegiatan Kepala Desa terlebih dahulu menyampaikan usulan rencana kegiatan dari Pemerintah Desa dan sebagian besar kegiatan tersebut disetujui, bukan berarti adanya dominasi dari Kepala Desa Merarai Dua. Hal itu disebabkan karena kegiatan yang telah disetujui dan ditetapkan merupakan hasil musyawarah yang telah disepakati bersama, dan merupakan kebutuhan dan prioritas kegiatan untuk Tahun 2019.

Dalam kaitannya dengan perencanaan pemanfaatan Alokasi Dana Desa (ADD) ini, kendala sosio-ekonomi terjadi karena tidak tersedianya dana yang cukup dalam proses perencanaan, sehingga akan berpengaruh terhadap perencanaan yang akan dihasilkan. Keterbatasan dana ini mengandung dua pengertian. Yang pertama adalah terbatasnya atau minimnya jumlah Alokasi Dana Desa yang dialokasikan oleh pemerintah kabupaten kepada desa-desa khusunya Desa Merarai Duasehingga banyak usulan rencana kegiatan yang tidak dapat diakomodir di dalam Anggaran Pendapatan Belanja Desa Merarai Duauntuk dilaksanakan pada Tahun 2019 pada hal kegiatan tersebut sangat penting bagi masyarakat. Pengertian yang kedua adalah keterbatasan dana dalam hal persiapan dan penyelenggaraan rapatrapat serta penyiapan administrasi penunjang dalam rangka penyusunan dokumen Rencana Kerja Anggaran dan Raperdes Anggaran Pendapatan Belanja Desa Merarai DuaTahun 2019. Biaya penunjang tersebut antara lain untuk keperluan alat tulis kantor, biaya fotocopy, biaya konsumsi rapat serta bantuan untuk biaya transportasi.

\section{KESIMPULAN DAN SARAN}

Kesimpulan hasil penelitian sebagai berikut:(a). Pelaksanaan Kebijakan Alokasi Dana Desa (ADD) di di Desa Merarai Dua dilakukan melalui beberapa tahapan, yakni tahap perencanaan, penggunaan anggaran, maupun pengawasan. (b). Penggunaan angaran teah disesuaikan dengan perencanaan dan telah dilakukan sesuai prosedur namun namun belum mencakup semua kebutuhan desa yang riil.(c). Pengawasan dana dan dukungansumberdaya perangkat desa dan motivasi telah dilakukan dan tersedia cukupa memadai.Saran:(a).Perencanaan, Penggunaan dan Pengawasan Anggaran Dana Desa (ADD) diharapkan dapat dilakukan sebagaimana yang telah ditentukan dalam Anggaran Pendapan dan Belanja Desa (APBDes) serta peraturan perundang-undangan tata pengelolaan keuangan yang berlaku. Laporan 
Darmawan,Petrus,Asrori, Tata Pengelolaan Alokasi Dana Desa (ADD) 155

keuangan juga merupakan hal penting yang harus dilaksanakan secara teliti dan tepat yang disertai dengan bukti-bukti kelengkapan administrasi laporan pertanggungjawaban.(b).

Dalam melaksanakan penyusunan Anggaran Penerimaan dan belanja Desa (APBDes), terutama yang berhubungan dengan pelaksanaan Angaran Dana Desa ADD), diharapkan pemerintah Kabupaten Sintang mengembangkan sumber daya manusia desa dalam hal ini perangkat desa, mengupayakan sarana dan prasarana desa yang memadai serta meningkakant daya kompetensi aparatur.

\section{DAFTAR PUSTAKA}

Arikunto, S. 2000. Prosedur Penelitian, Suatu Pendekatan Praktek. Jakarta: Rineka Cipta.

Danim, S. 1997. Pengantar Studi Penelitian Kebijakan. Jakarta: Bumi Aksara.

Dunn, W.N. 2000. Pengantar Analisis Kebijakan Publik. Penerjemah: Samodra W., Diah, A. Agus, H. H. Erwan.AP. Edisi Kedua. Yogyakarta: Gajahmada University Press.

Faisal, S. 2005. Format-Format Penelitian Sosial. Jakarta: PT. RajaGrafindo Persada.

Handoko, T.H. 2000. Manajemen Sumber Daya Manusia. Yogyakarta: BPFE

Hanafi, A dan Waseso, G.M. 1994. Penelitian Mengevaluasi Efektivitas Program Kemasyarakatan. Surabaya: Usaha Nasional.

Jones, CO. 1991. Pengantar Kebijakan Publik. Editor Nashir Budiman. Jakarta: Rajawali Press.

Kusnadi, HMA. 2005. Pengantar Manajemen: Konsepsual \& Perilaku. Malang: Unibraw Press.
Sarundajang. 2001. Arus Balik Kekuasaan Pusat ke Daerah. Jakarta: Pustaka Sinar Harapan.

Sule, ET. Dan Kurniawan Saefullah.2005. Pengantar Manajemen. Jakarta: Kencana.

Sedarmayanti. 2001. Dasar-dasar Pengetahuan Tentang Manajemen Perkantoran. Bandung: Mandar Maju.

Siswanto, HB., 2005. Pengantar Manajemen. Jakarta: Bumi Aksara.

Siagian,S.P. 2003. Filsafat Administrasi. Jakarta: Gunung Agung.

Siagian, S.P. 1982. Administrasi Pembangunan. Jakarta: Gunung Agung.

Supriatna. 1985. Dimensi Pembangunan Nasional. Jakarta: Bumi Aksara.

Suparmoko, M. 1994. Keuangan Negara Dalam Teori dan Praktek. Edisi Keempat. Yogyakarta: BPFE UGM.

Samuelson, P.A dan Nordhaus. 1994. Makro Ekonomi. Jakarta: Erlangga.

Syamsi. 1994. Dasar-Dasar Kebijaksanaan Keuangan Negara. Edisi Keempat. Jakarta: Rinneka Cipta.

Umar, H. 2005. Riset Sumber Daya Manusia Dalam Organisasi. Jakarta: Gramedia Pustaka Utama.

Wibawa, S.1992. Laporan penelitian Studi Implementasi Kebijakan Publik. Jakarta: RajaGrafindo Persada. 1994. Evaluasi Kebijakan Publik. Jakarta: RajaGrafindo Persada.

Winarno, B. 1989. Teori Kebijakan Publik. Yogyakarta: Bina Aksara Universitas Studi Sosial UGM. .2005. Kebijakan Publik: Teori \& Proses. Jakarta: Bumi Aksara. 